\title{
Second Times Microgram per Milliliter
}

National Cancer Institute

\section{Source}

National Cancer Institute. Second Times Microgram per Milliliter. NCI Thesaurus. Code C85805.

Seconds times micrograms per milliliter. 